\title{
Subjective Thinking: Kierkegaard on Hegel's Socrates
}

\section{Daniel Watts}

One of the more surreal moments in Kierkegaard's journals involves a scene from the Underworld. Hegel has been reading Trendelenburg's Logical Investigations, and goes over to Socrates to complain. Alas, the conversation has trouble getting off the ground:

Socr.: Should we begin by being altogether in disagreement, or should we agree on something we could call a presupposition? .... What do you presuppose as your starting-point?

H.: Nothing at all.

Socr: That's quite something! So perhaps you don't start at all?

H.: I not start, I who have written 21 volumes?

Socr: Ye gods, what a hecatomb you have offered!

H.: But I start from nothing.

Socr.: Is that not something?

H.: No - on the contrary. That first makes its appearance in the conclusion of the whole, in the course of which I discuss science, world history etc.

Socr.: How might I be able to master this difficult task for many remarkable things may well be included which would show up my stupidity... You know that I did not even allow Polos to talk more than 5 minutes at a time, and you want to talk XXI volumes. ${ }^{1}$

This unfinished sketch did not make it into the published works. But it is certainly in the spirit of the kind of juxtaposition we find throughout Concluding Unscientific Postscript between the Hegelian philosopher and the Socratic thinker, the sophisticated systembuilder and the simple wise man of Greece. ${ }^{2}$ And the ability to say what exactly is at issue in these satirical comparisons is no doubt a basic condition of the adequacy of any account of Kierkegaard's relations to Hegel in general. It is also clear enough that such comparisons go to the heart of Kierkegaard's own understanding of his work as an author. His readiness to identify himself with Socrates is scarcely less marked than his readiness to distance himself from Hegel, and 'the Danish Socrates' has long been a stock figure in the secondary literature. ${ }^{3}$ In a well-known late text, Kierkegaard goes so far as to 
lay claim to Socrates as the 'one and only analogy' for his life's work as a whole (Kierkegaard 1998: 341).

This retrospective view of Socrates as a constant point of reference is, of course, already foreshadowed by the title of Kierkegaard's magister dissertation The Concept of Irony with Continual Reference to Socrates. Now, one central feature of this work is that it proposes a self-styled 'modification' of Hegel's view of Socrates. And my aim in this essay is simply to provide a satisfying interpretation of this part of Kierkegaard's early critical response to Hegel. But we may note in general that, whatever story there is to tell about the evolution of his thought in this regard, it is certainly plausible that Kierkegaard's later view of Socrates, together with his satirical comparisons between the Socratic thinker and the speculative philosopher, emerge out of his early confrontation with the picture of Socrates he found in Hegel. ${ }^{4}$ Plausibly, then, Kierkegaard's critical response to Hegel's Socrates in The Concept of Irony decisively shaped his relationship to Hegel more generally, and indeed his mature self-conception as thinker and author.

If important things turn on how we are to understand the early Kierkegaard's response to Hegel's view of Socrates, we shall see, however, that the question is both contested and difficult. The basic puzzle, as Lee Capel nicely put it, is how it can be that Kierkegaard's approach seems to be 'so thoroughly dependent upon Hegel's conception of Socrates in all its significant detail, and yet add up to such a wholly different totality' (Capel 1971: 403n31). On the interpretation I shall defend, the crucial question is how we are to understand the basic idea that Socrates serves to exemplify a certain kind of thinking. We shall see that Kierkegaard shares with Hegel the view that Socrates does indeed exemplify a certain kind of thinking, that his doing so is part and parcel of his significance as a turning-point in the history of philosophy, and that what is most distinctive about his way of thinking can be characterised in a general way by saying that it is essentially both 'objective' and 'subjective'. But this characterisation is scarcely transparent and the question is how we are to spell it out. And we shall see that the 'modification' to Hegel's view of Socrates that Kierkegaard proposes in The Concept of Irony is plausibly regarded as a rival way of spelling out these ideas.

The crux of the dispute, I shall argue, comes to this. In Hegel's view, Socratic thinking is 'objective' in the sense that it is constituted by the primary aim to grasp universal definitions of certain concepts, most especially the Good; it is 'subjective' in the sense that Socrates takes up the search for objective definitions by relying on his own power of judgement qua rational thinker. In Kierkegaard's view, by contrast, the interrogation of particular thinkers enters into Socrates' most basic aims and interests, and no less so than the demand for objective definitions. Kierkegaard thinks that what really singles Socrates out as a thinker is his special interest in particular thinkers, as those who are properly subject to the demand for objective definitions of basic ethical concepts, and especially the Good. On this view, Socratic thinking is essentially both 'subjective' and 'objective' in a sense that contrasts with Hegel's, that is, in the sense that 


\section{Daniel Watts}

it is constituted by the aim to examine particular thinkers, by seeking to establish that they are properly subject to the demand for objective definitions.

It is not part of my aim in this essay to adjudicate between Hegel and Kierkegaard as readers of the primary sources on Socrates. But I do hope to bring out something of the philosophical interest and import of their dispute about the nature of Socratic thinking, especially in the light of Hegel's appraisal of such thinking. Hegel evidently thinks that Socrates falls short of the objective knowledge he seeks, and that he fails in this way because of the 'subjective' character of the kind of thinking he serves to exemplify. I shall argue that The Concept of Irony provides the materials for a cogent defence of Socratic thinking in this regard, even if these materials are not fully exploited in the dissertation itself. This defence relies on the way Kierkegaard develops his alternative to Hegel's account of the basic aims of Socratic thinking, which I shall present in terms of a three-fold characterisation of such thinking as distinctively situated, inquisitive and reflexive. On the view that emerges, to give up that which Hegel finds wanting in Socratic thinking would be to abandon, not to advance, the basic aims of such thinking.

\section{I}

Part One of The Concept of Irony undertakes an avowedly paradoxical project, namely, to make manifest Socrates' true nature as a radical 'ironist', that is, as one whose true nature is always to remain concealed. ${ }^{5}$ Given the overtly Hegelian framework within which this project is developed, one natural question is how it stands in relation to Hegel's own view of Socrates. Kierkegaard takes up this question directly in an appendix to Part One, entitled 'Hegel's View of Socrates' (CI: 219ff). The burden of this appendix seems to be to show that, on the whole, Hegel's position is compatible with the view of Socrates as an ironist of an unqualifiedly destructive sort. Moreover, Kierkegaard claims that, despite inconsistencies in his various remarks about Socrates, Hegel comes very close to endorsing this very conception, in substance if not expressly in terms of irony. The appendix nonetheless registers two chief complaints. The first is that, against his own best judgements, Hegel frequently gives way to the temptation to attribute to Socrates a positive conception of the Good. The second is that, in Kierkegaard's words, '[a]lthough Socrates himself places much weight on his divine mission, Hegel has ignored this' (CI: 236).

Thus, the appendix on Hegel sounds an ambivalent note. On the one hand, it parades the Hegelian credentials of the view of Socrates Kierkegaard has supposedly shown to be not only possible but also actual and necessary; on the other hand, it leans on this same account to gain critical leverage against Hegel. And, as many commentators observe, this kind of equivocation runs throughout the dissertation. Let me begin, then, by briefly considering two kinds of approach to Kierkegaard's apparent ambivalence towards Hegel's Socrates. My aim here is not to provide a full critical appraisal of any particular reading of The Concept of Irony but rather to indicate in a preliminary way some 
of the difficulties surrounding the question of the relationship between the two conceptions, and some of the constraints on a plausible answer.

Consider first what we might call the conciliatory approach. On this strategy, we are to suppose that Kierkegaard's account is indeed basically consonant with Hegel's view of Socrates, and that what The Concept of Irony offers is essentially a development of this view. In a recent essay, Jon Stewart clearly articulates a conciliatory approach as follows:

Kierkegaard seems wholly to agree with Hegel's assessment that Socrates represents the principle of subjective freedom; he elaborates on it in a slightly different way by emphasising irony, which, although treated by Hegel, does not play the central role for him. What Kierkegaard understands by irony is part of what Hegel calls the principle of subjective freedom. (Stewart 2007: 112-13)

At one point in the appendix, Kierkegaard reaches for the term 'modification' to pick out his own view in relation to Hegel's, and Stewart evidently thinks this term is perfectly felicitous. Certainly, there is compelling textual support for the claim that Kierkegaard endorses the idea that Socrates represents what Hegel calls the principle of subjective freedom. Indeed, Kierkegaard repeatedly appeals to Socrates' 'ironic freedom' in relation to the customs, mores and laws of his given actuality. ${ }^{6}$ Moreover, as Stewart also observes, Kierkegaard follows very closely Hegel's account of the significance of Socrates' daimon as a kind of intermediary between the external oracle and unqualified subjective freedom. What, then, of Kierkegaard's less commodious remarks about Hegel's Socrates? Stewart continues:

[Kierkegaard] tends to overstate his case in order to distinguish his view from that of Hegel. He agrees with Hegel's interpretation of the role of Socrates in world history and in a sense can be seen as expanding Hegel's analysis by further developing Hegel's account of Socratic irony and understanding it in terms of the Hegelian principle of subjective freedom. (Stewart 2007: 114)

An attractive feature of Stewart's reading is that it makes plain sense of well-known passages in later writings in which Kierkegaard takes his earlier self to task for being in the thrall of Hegel. It seems to me, however, that the conciliatory approach is unduly irenic for three main reasons.

Firstly, and most straightforwardly, it is very plausible that the explicit criticisms of Hegel in The Concept of Irony reflect disagreement of a kind that cuts deeper than a slight shift in emphasis and terminology. Consider, for example, the objection which Kierkegaard most fully articulates in the appendix and which he introduces as follows: 


\section{Daniel Watts}

The real difficulty with Hegel's view of Socrates is centred in the continual attempt to show how Socrates interpreted the Good, and what is even more wrong in the view, as I see it, is that it does not accurately adhere to the direction of the trend in Socrates' life. (CI: 235)

This objection plainly relies on the idea that it is somehow a mistake to try to specify Socrates' conception of the Good. And we must return to the question of why Kierkegaard thinks this is so. As this passage makes clear, however, he also thinks there is a deeper sense in which Hegel's approach is objectionable, namely, in its alleged insensitivity to Socrates' whole orientation, 'the direction of the trend in Socrates' life'. Kierkegaard is careful here neither to identify this deeper failing with the attempt to specify Socrates' conception of the Good, nor to present the former as a consequence of the latter. And we may add that it does not directly follow from the claim that it is a mistake to try to specify Socrates' conception of the Good that to do so would be to miss something crucial about the whole orientation of his life. For one might hold, for example, that our reasons not to try to specify Socrates' conception of the Good are reasons to suppose he failed in the basic task he set himself, viz. to acquire knowledge of the Good. Indeed, as we shall see, this sometimes seems to be just Hegel's view. But Kierkegaard's striking claim is that Hegel misses something crucial about the basic character and orientation of Socrates' philosophical practice, so the interpretative challenge is, I take it, to specify just what it is he thinks that gets fundamentally obscured in Hegel's account.

A second weakness of the conciliatory strategy is that it leaves The Concept of Irony especially vulnerable to an obvious rejoinder from a defender of Hegel's unmodified view of Socrates. According to this rejoinder, Kierkegaard 'develops' this view only in the sense that he simplifies and distorts it, by lopping off just one side of Hegel's careful and dialectically nuanced attempt to do justice both to the destructive aspects of Socrates' role as representative of the principle of subjective freedom and to the constructive aspects of his search for essential knowledge. Moreover, as Robert Williams points out, this one-sidedness is especially puzzling - Williams says ironic - given that The Concept of Irony concludes with a defence of irony as a controlled factor in the construction of a positive world-view. ${ }^{8}$ In short, the conciliatory approach threatens to render Kierkegaard's 'modification' anodyne, undialectical and in internal tension with the commitment he shares with Hegel to the constructive power of irony.

Whilst the conciliatory approach sticks close to the letter of Kierkegaard's claims for the Hegelian pedigree of his view of Socrates, a third kind of worry is whether it does justice to their tone and spirit. One can perhaps hear in Kierkegaard's choice of the term 'modification', for example, a characteristic note of irony, indicating that he takes this to be just the kind of 'modification' that changes everything. And we might recall in this context Kierkegaard's complaint about Xenophon's lack of an ear for the 'reverse echoing' of Socrates' ironic rejoinders to his interlocutors (CI: 18). Of 
course, claims that an author is being ironical are never easy to establish, but if any text in our tradition gives special grounds for suspicion in this regard, this is surely Kierkegaard's The Concept of Irony. ${ }^{\text {? }}$

In the light of these considerations, one might well reach for a less emollient approach. Indeed, many commentators maintain that, despite his own protestations to the contrary, Kierkegaard's views on Socrates stand to Hegel's in a relationship of radical incompatibility and opposition. This agonistic approach is well exemplified by the treatment of The Concept of Irony in a recent book by David Kangas. In Kangas' view, the 'main concern' of Part One of the dissertation is to establish 'the irreducibility of the Socratic standpoint to its philosophical appropriation within the texts of Plato and Hegel' (Kangas 2007: 14). And Kangas offers the following, by way of an initial gloss on how this works out in relation to Hegel, in particular:

Both Hegel and Kierkegaard grasp Socratic interiority in terms of a turn toward 'being in and for itself. For both, the turn inward, which grasps being in its distinction from beings (or the Good in its distinction from particular goods), is presupposed in all philosophical cognition. Philosophy aims at the absolute as its sole object. But what is meant by the absolute? Here is where the difference emerges. To put it simply, for Hegel the absolute constitutes the totality of ontological determinations (the 'system' of the real); for Kierkegaard the absolute must be thought as ab-solute, that is, as what absolves itself of all determinations [...] The absolute is indeterminate (absolutely without determinations). (Kangas 2007: 20)

It is notable that Kangas shifts here from claims about what Kierkegaard and Hegel make of Socrates to claims about their own respective views of 'the absolute'. But the general idea is clear enough: Kierkegaard's so-called 'modification' involves nothing less than the attribution to Socrates of certain fundamental philosophical doctrines that are directly contrary to those attributed to him by Hegel. Specifically, the opposition amounts to this: whereas Hegel's Socrates is committed to the possibility of positive discursive knowledge of the Good, that is, knowledge of what the Good is, Kierkegaard's Socrates rejects the possibility of such knowledge in principle, on the grounds that the Good is indeterminate and indefinable. And Kangas goes on to claim that Kierkegaard bases his appeal to this apophatic doctrine on Socrates' self-understanding in terms of his 'divine mission'. What Kierkegaard thinks Hegel misses, in this view, is the religious foundation of Socrates' inquiries, specifically their basis in the recognition that, as Kangas puts it, '[t]o relate to the divine as the absolute is to abandon positive determinations' (Kangas 2007: 22). In short, the closest analogy to Kierkegaard's Socrates is the negative theologian.

Kangas is able to draw on many striking, if notoriously elusive, passages in which Socratic irony is associated with negativity, infinite deferral, 'the nothing' and so forth. ${ }^{10}$ Nonetheless, an agonistic approach faces serious difficulties, too - and this is so even if 


\section{Daniel Watts}

one puts aside that it must somehow accommodate Kierkegaard's repeated claims for the Hegelian credentials of his view as a whole. For one thing, it is hard to find in The Concept of Irony anything that looks like the attribution to Socrates of an argument for his supposed metaphysical commitments, that is, putative reasons for believing that the Good is indeterminate and indefinable. And we may note that Kangas' appeal in this context to Kierkegaard's emphasis on Socrates' self-conception as a divine emissary is far from decisive in this regard. After all, Kierkegaard never says that the indeterminacy of the Good (or the divine or the absolute) is entailed by Socrates' understanding of his 'mission'; as we shall see, there are other interpretative possibilities here.

More importantly, however, Kangas' reading is hard to square with some of the most central and prominent things Kierkegaard does say about Socrates. It is emphasised throughout the dissertation, for example, that Socrates' professions of ignorance are no mere starting point, or conversational technique, but a hard-won achievement, the 'negative conclusion' of Socrates' inquiries. But Kierkegaard is careful to distinguish Socrates' professions of ignorance from any kind of scepticism which relies on a claim to knowledge, the claim to know of some thing, $\mathrm{X}$, that it cannot be known what $\mathrm{X}$ really is. ${ }^{11}$ What is special about Socrates, Kierkegaard insists, is that he disclaims all discursive knowledge of the highest things, all knowledge of these things of the form ' $\mathrm{X}$ is $\mathrm{F}$. ${ }^{12}$ And it ought to be clear that this sits uneasily with the idea that Socrates somehow thinks he knows of the highest things that these things are essentially indeterminate and indefinable.

Finally, it is not clear that the agonistic approach fares much better than does the conciliatory reading in finding in The Concept of Irony a plausible response to Hegel's view of Socrates. To be sure, Kierkegaard's 'modification' is hardly anodyne on a view like Kangas'. But Williams forcibly articulates the obvious objection to Kierkegaard, on this kind of reading:

Kierkegaard's interpretation tends to confuse two quite different things: the sophistic view that knowledge is impossible because there are no stable objects to be known, and the Socratic demonstration via irony that what is usually called knowledge is not knowledge at all [...] [T] he negations of Socratic irony imply knowledge, knowledge that radical irony denies, but which Hegel, following the more traditional view of Socrates, affirms. (Williams: 2002: 77)

Of course, one may wish to try to defend Kierkegaard against this objection, but it ought at least to be clear that the burdens of charity on an interpretation like Kangas' are relatively demanding.

These remarks are perhaps sufficient to indicate some of the difficulties surrounding the question of how Kierkegaard's early view of Socrates stands in relation to Hegel's, and some of the constraints on a plausible answer. In the rest of this essay, my 
aim is to work within these constraints towards a more satisfying interpretation. In the end, the view I shall defend is more agonistic than conciliatory. But it does not rely on the idea that Kierkegaard's Socrates thinks he knows the Good is indeterminate or indefinable, and it does take seriously the idea that Kierkegaard begins with some key Hegelian insights about Socrates.

\section{II}

Expositors of Hegel's view of Socrates tend to home in on the ideas of subjective freedom and reflective morality. ${ }^{13}$ But it is crucial for Hegel that these ideas only partially specify Socrates' place in the history of philosophy, which he construes more widely in terms of a radically new and distinctive kind of thinking. In the first paragraph of the section on Socrates in his Lectures on the History of Pbilosophy, Hegel announces Socrates as a 'mental turning-point ... in the form of philosophic thought' (Hegel 1995: 384). And a little further down, he offers the following by way of an account of what this turningpoint consists in vis-à-vis the Sophists:

Reflection, and the reference of any judgment to consciousness, is held by Socrates in common with the Sophists. But the opposition into which Socrates and Plato were in their philosophy necessarily brought in regard to the Sophists, as the universal philosophic culture of the times, was as follows: - The objective produced through thought, is at the same time in and for itself, thus being raised above all particularity of interests and desires, and being the power over them. Hence because, on the one hand, to Socrates and Plato the moment of subjective freedom is the directing of consciousness into itself, on the other, this return is also determined as a coming out from particular subjectivity. It is hereby implied that contingency of events is abolished, and man has this outside within him, as the spiritual universal. This is the true, the unity of subjective and objective in modern terminology, while the Kantian ideal is only phenomenal and not objective in itself. (Hegel 1995: 387)

These are dark sayings, no doubt, and seem to place Socrates rather further along in the historical development than he should be. One thing seems relatively clear, however: to say that Socratic thinking is 'subjective' or 'inward' is not, for Hegel, to say that such thinking is primarily of or about individuals' subjective states. The idea is not that Socrates devoted himself to the contemplation of his own episodic acts of thinking or token psychological states. On the contrary, Hegel insists that Socrates was ultimately oriented towards that which objective, necessary and universal, towards 'being-in-andfor-itself in Hegel's terms of art. Socratic thinking goes beyond the 'particularity of interests and desires' in its search for objective definitions, Ideas and essences. This, 


\section{Daniel Watts}

indeed, is what Hegel thinks singles out Socrates from the relativistic Sophists, who also help to usher in the age of critical reflection and subjective freedom, but who fail to make the Socratic movement of 'coming out from a particular subjectivity' by taking up the search for universal definitions of basic ethical concepts. ${ }^{14}$

There are perhaps several ideas tangled up in Hegel's characterisation of Socratic thinking as nonetheless 'subjective'. But foremost in Hegel's exposition is the idea that the way in which Socrates takes up the search for objective definitions relies on his own power of judgement qua rational thinker. 'Socrates' principle', Hegel says, is that 'human beings have to discover and learn from themselves [...] what is true in and for itself; they must attain truth by and through themselves' (Hegel 2006: 124-25). It is thus constitutive of Socratic thinking, on Hegel's account, to search for objective essential knowledge, and to do so by relying solely on one's own power of judgement qua rational thinker. ${ }^{15}$ No doubt, it is also part of Hegel's view that Socrates operates with a less than purely abstract and objective conception of rational thought itself; in Socrates, he writes, thought shows itself 'only partly as abstract principle and partly as contingent subjectivity' (Hegel 1995: 165). But it ought to be clear that it is not Hegel's view that Socratic thinking is essentially directed towards the contingent performances of particular thinkers as such.

Now, at one point early on in The Concept of Irony, Kierkegaard invokes a comparison between Socrates and (post-) Kantian idealism in a way that seems to echo these Hegelian ideas:

The direction that manifested itself in [(post-)Kantian] idealism as reflection upon reflection manifested itself in Socrates' questioning. To ask questions - that is, the abstract relation between the subjective and the objective - ultimately became the primary issue for him. (CI: 37)

These sentences pick up many of the key themes in Hegel's conception of Socratic thinking: reflection, reflexivity, idealism, the subjective and the objective. But there also appears to be a contrast here: for Hegel would surely regard the ultimate issue for Socrates as a matter of trying to find answers - objective answers to Socratic questions about the Good, the Just, the Beautiful and so forth — and not, as Kierkegaard seems to indicate, primarily as a matter of asking questions. What, then, does Kierkegaard make of Hegel's conception of Socratic thinking as the pursuit of objective knowledge through subjective thinking?

In broad outline, the interpretation I propose is this. Like Hegel, Kierkegaard holds that Socrates exemplifies a distinctive way of thinking. And like Hegel, he too is impressed by the possibility of parallels between Socrates and (post-)Kantian idealism in this regard, and especially by the idea that Socratic thinking is somehow both subjective and objective. But here's the rub. Kierkegaard wants to show, contra Hegel, that the 
contingent performances of particular thinkers enter into Socrates' most basic aims and interests.

More specifically, Kierkegaard thinks that what constitutes Socrates' philosophical practice is the interest he primarily takes in particular thinkers, as those from whom an objective definition of some basic ethical concept is properly required. He thinks it is constitutive of Socratic thinking to examine particular thinkers, by seeking to demonstrate that they are properly subject to the demand for an objective definition of some basic etbical concept. On this account - which I shall try to explain more fully in Section III below - it belongs to Socrates to seek to show, in a given conversation, that an individual's grasp of the central concept under discussion, whether his own or that of another thinker, is such as to warrant the demand for an objective definition. In other words, Socrates' primary aim is to show that this demand is not one that is imposed from without, in a merely external or arbitrary way, but one that emerges as a genuine imperative for particular thinkers, given their existing grasp of basic ethical concepts and, especially, of the Good.

On the interpretation I want to defend, Kierkegaard's dissertation offers an alternative to Hegel's way of spelling out the idea that Socratic thinking is both objective and subjective. Very schematically, Socratic thinking is 'objective', on Kierkegaard's view, in the sense that it essentially involves seeking to establish in particular cases that an objective definition of some basic ethical concept is required; it is 'subjective' in the sense that it essentially involves examining the contingent performances of particular thinkers; and it is essentially and jointly both of these things because such thinking is constituted by the attempt to demonstrate that particular thinkers are properly subject to the demand for objective definitions. This is, in general, how I think we should understand Kierkegaard's claim that for Socrates the 'relation between the subjective and the objective ... ultimately became the primary issue'.

We can begin to establish and spell out this interpretation by observing that Kierkegaard apparently intends his formulation of 'the primary issue for Socrates' to bring under a single and summary description two essential features of Socratic thinking. In the first place, he emphasises what we may call the content-directedness of Socrates' thought. Thus, at the outset of his discussion of Plato's so-called Socratic dialogues, he offers the following general gloss on what makes these dialogues genuinely Socratic, a formula he will recite more than once:

[T] he Socratically disciplined dialogue is an attempt to allow the thought itself to emerge in all its objectivity ... The method is essentially one of simplifying life's multifarious complexities by leading them back to an ever more abstract abbreviation.

It is thus typical of Socrates to take up 'What is F?' questions, proceeding, as Kierkegaard likes to say, from 'the phenomenon' towards 'the Idea', 'the thought itself. Since it is familiar that Kierkegaard emphasises the ironic and negative features 


\section{Daniel Watts}

of the Socratic dialogue, it is noteworthy that he also underlines this transparent, positive aim. Indeed, he presents this as the 'dialectical' element which marks out the genuinely Socratic from the tendency in Plato towards the mythical and the speculative; it is also what singles out Socrates from the Sophists who know how to make speeches but not how to say the same about the same; it is what enables Socrates to 'begin anywhere', without prejudice; and it determines Socrates' maieutic role as the teacher who 'cut $[\mathrm{s}]$ the umbilical cord' of the learner's immediate attachments. ${ }^{16}$ Nowhere does Kierkegaard indicate, for instance, that he thinks Socrates' commitment to 'stick to the subject', to the content of the argument, can be put down to mere posture or ruse - Richard Robinson's 'Socratic slyness' - intended merely to trick others into having their views refuted. ${ }^{17}$ Quite to the contrary, Kierkegaard readily invokes 'this Socratic earnestness, which attaches itself to its subject-matter as alertly and assiduously as a prison guard to his prisoner' (CI: $34 n$ ).

However, The Concept of Irony also sounds a different and seemingly dissonant note. Consider, for instance, the following passage, which comes just a few pages later:

Socrates' questioning was essentially aimed at the knowing subject for the purpose of showing that when all was said and done they knew nothing whatsoever. Every philosophy that begins with a presupposition naturally ends with the same presupposition, and just as Socrates' philosophy began with the presupposition that he knew nothing, so it ended with the presupposition that human beings know nothing at all. (CI: 37)

Socrates' questioning is now said to target 'the knowing subject', and essentially so. But given that 'the knowing subject' evidently means here individual human beings qua possible knowers, it is difficult to see how this aim could possibly converge with a general orientation away from that which is concrete and particular and towards that which is abstract and universal. ${ }^{18}$ Indeed, the reader would be forgiven for complaining that Kierkegaard's account pulls in opposite directions here. For how are we to reconcile the idea that Socratic thinking is earnest and content-directed with the idea that such thinking is ironical and persons-directed? And how are we to square Kierkegaard's sense of the free-standing and wide-ranging nature of Socratic inquiry with his insistence on Socrates' well-defined 'mission' to destroy illusions of knowledge through elenchoi, in the sense of the examination of particular thinkers, and the claims they happen to make?

The answer to these questions clearly cannot be that Kierkegaard thinks of Socrates as engaged in two separate kinds of inquiry, the one essentially involving the examination of persons, the other the examination of propositions, arguments, proposed definitions and the like. Kierkegaard's manifest aim is to provide a unified general account of 'what properly belongs to Socrates' and of the distinguishing marks of Socratic thinking, conceived as a single kind. ${ }^{19}$ In this regard, he clearly follows Hegel in presenting Socrates as a new kind of thinker. But neither is it at all plausible that 
Kierkegaard simply relies on Hegel's conception of the Socratic search for definitions through subjective reflection. One thing which tells decisively against this suggestion is that Kierkegaard expressly dissociates Socratic irony from subjective thinking in Hegel's sense. 'There is often a deceptive similarity between subjective thinking and irony', he writes, adding, however, that subjective thinking is 'positive' in a way that Socratic irony is not (CI: 123).

My argument, then, is that the opening sections of The Concept of Irony are only really intelligible if, pace Hegel, Kierkegaard thinks of it as Socrates' primary aim to examine particular thinkers, as those who are properly subject to the demand for objective definitions. For he may then suppose that it is part of this aim to demonstrate, case by case, that the demand for an objective definition is warranted. This plausibly explains the earnest, transparent, content-directed character of the Socratic dialectic in Kierkegaard's view. By the same token, however, he may also regard it as part of Socrates' overall aim to work to render questionable particular thinkers' grasp of the basic concepts under discussion, and to destroy their illusions of knowledge and understanding in this regard. And this part of the aim plausibly explains the singularly destructive and personal character of the Socratic elenchos in Kierkegaard's view.

Before turning to spell out this line of interpretation in more detail, we may also note that it promises to illuminate the relationship between the masters' dissertation and later works by Kierkegaard, especially Concluding Unscientific Postscript. As we have seen, in the earlier work, Socrates is clearly dissociated from 'subjective thinking'. In this light, it is arresting to find Socrates held up in the Postscript as the paradigm and exemplar of the subjective thinker: indeed the concept of subjective thinking is more or less defined in this work by reference to Socrates. ${ }^{20}$ Now, it would be a wholly implausible solution to this puzzle to suppose that Kierkegaard has meanwhile come round to Hegel's view, for it is clear that the conception of subjective thinking developed in the Postscript is quite different from Hegel's. Johannes Climacus introduces his conception of subjective thinking as follows:

The reflection of inwardness is the subjective thinker's double-reflection. In thinking, he thinks the universal, but, as existing in this thinking, as acquiring this in his inwardness, he becomes more and more subjectively isolated. (Kierkegaard 1992: 73)

It is clear that the sense in which doubly reflective thinking is 'subjective' here is the sense in which it is directed not only towards abstract ideas, propositions, arguments and the like, but also towards the concrete particularity of the individual thinker. Thus, one of the central claims of the Postscript is that one ought to reflect on the general question of what it is to be a human being in relation to oneself, an 'existing individual', as Climacus likes to say. And whatever else is true of this conception of subjective thinking, 


\section{Daniel Watts}

it ought to be clear that it is not what Hegel calls subjective thinking, that is, thinking that relies solely on the thinker's own power of judgement qua rational subject.

An attractive feature of our interpretation is that it allows us in this way to regard Kierkegaard's later conception of subjective thinking in continuity with his early view of Socrates. As we shall now see, there is reason to think that even the early Kierkegaard's so-called 'modification' of Hegel's Socrates makes all the difference in relation to the more evaluative dimensions of Hegel's view.

\section{III}

If he sometimes writes as though Socrates ought to have come some time after Kant, Hegel elsewhere makes it clear that Socrates, like any other individual, is a child of his age, one who 'may give himself airs as he likes but ... does not transcend his time' (Hegel 1985: 49-50). This is especially clear when Hegel comes to reflect in a more critical way on the nature of Socratic thinking. Consider, for example, the following two passages, the first from the Encyclopaedia Logic $\$ 81$ and the second from the Lectures on the History of Philosophy:

Among the ancients, Plato is called the inventor of the dialectic, and this is quite correct in that it is in the Platonic philosophy that dialectic first occurs in a form which is freely scientific, and hence also objective. With Socrates, dialectical thinking still has a predominantly subjective shape, consistent with the general character of his philosophising, namely that of irony. Socrates directed his dialectic first against ordinary consciousness in general, and then, more particularly, against the Sophists. (Hegel 1991: 129)

In [the history of] culture or human consciousness it was Socrates who discovered that the Good is the end in and for itself ... It is an inwardly concrete principle but one that is not yet apprehended in a concrete definition, and this abstract stance is the deficiency of the Socratic principle. There is nothing further of an affirmative nature that we can point to, for it has no further elaboration. (Hegel 2006: 136)

On Hegel's appraisal, then, there is something wanting in Socrates' philosophical practice, the fulfilment of which must wait until later developments in dialectic. Specifically, Socrates fails to achieve a more-than-merely-abstract conception of the Good, and he fails in this way because of the subjective and unsystematic character of the kind of thinking he exemplifies. In its intimate connections with ordinary life, Hegel remarks, Socrates 'does not proceed to a system' and so falls short of the 'free, pure regions of thought' (Hegel 1995: 396). ${ }^{21}$ 
Whilst it is typical of Hegel's reflections on Socratic thinking to invoke a critical comparison with a purer, more systematic approach, his criticisms are clearly supposed to be internal rather than external. As we have already emphasised, Hegel denies that it is any part of Socrates' own basic aims to discover contingent facts about particular thinkers; rather, the kind of thinking he exemplifies is wholly aimed towards 'being-inand-for-itself. The form of Hegel's criticism must, therefore, be that, in his role as subjective thinker, Socrates lacks the methodological machinery needed in order to realise the goods internal to his own philosophical practice. ${ }^{22}$

Kierkegaard is, of course, often associated with a direct assault on Hegel's conception of pure thought and systematic philosophy. ${ }^{23}$ But we ought to be clear that no such attack is launched in his masters' dissertation. In fact, the initial impression, at least, is rather to the contrary since Kierkegaard seems happy to work within the terms of Hegel's comparison between Socratic thinking and modern speculative philosophy. ${ }^{24}$ I want to show now that nonetheless The Concept of Irony does provide materials for a cogent defence of Socratic thinking against Hegel's criticism.

The basic structure of this defence is straightforward. By offering an alternative account of Socrates' basic aims and interests, Kierkegaard rejects the descriptive basis for Hegel's appraisal. That is to say, it is because he takes it to be Socrates' primary aim to discover objective answers to 'What is F?' questions that Hegel regards Socrates' lack of a systematic method of answering such questions as an internal flaw in the kind of approach he exemplifies, viz. subjective thinking in Hegel's sense. But Kierkegaard denies the premise that Socrates' primary aim is to discover objective answers to 'What is F?' questions. He may, therefore, concede that if it were true that Socrates primarily set out to discover objective definitions, then Hegel's censure would be warranted; what Kierkegaard denies is the antecedent of this claim.

In order to assess whether Kierkegaard provides a cogent defence of Socrates along these lines, we must consider how he develops the idea of a kind of thinking whose primary aim is to examine particular thinkers, as those who are properly subject to the demand for objective definitions. In fact, I think the opening sections of The Concept of Irony provide a rather detailed articulation of this idea, which we may reconstruct in terms of three further specifications of Socratic thinking: as distinctively situated, inquisitive and reflexive. I shall consider these characterisations in turn, though we shall see that they are closely interconnected and must be understood together.

Firstly, then, Socratic thinking is distinctively situated. It is this feature that Kierkegaard finds perspicuous in its absence from Xenophon's portrait of Socrates, and which, he claims, renders this portrait so one-dimensional and distorted. Especially in comparison with Plato, what Xenophon signally lacks is 'an eye for situation', as Kierkegaard puts it (CI: 18). The idea here is not that Xenophon fails to place Socrates within his rightful cultural or intellectual milieu, or even that he underestimates the degree to which Socrates' conversations were shaped by such contexts, but that he misses the crucial significance of situation to Socrates, as a value that informed his whole outlook 


\section{Daniel Watts}

and approach. 'Situation was immensely important to Socrates' personality', Kierkegaard writes, adding that this must have shown itself in Socrates' 'secretive presence in ... the multicoloured variety of exuberant Athenian life' (CI 16). How are we to understand this?

The term 'situation' sometimes invokes the idea of an empirical or practical context. But Kierkegaard certainly does not mean to say that Socrates especially prized the values of applicability, adaptability, utility, aptitude and the like. To the contrary, he roundly criticises Xenophon for 'only taking the external into account', confusing Socrates' abstract inquiries into the Good with empirical searches for the most useful means to practical ends. ${ }^{25}$ In short, the one thing Kierkegaard thinks Xenophon cannot be accused of lacking is an eye for the quotidian.

It is also clear that Kierkegaard does not mean to say that Socrates' inquiries are 'situated' in the sense that they somehow take for granted shared traditions of belief or endoxa, that is, reputable bodies of opinion. Apart from the puzzle of why he should advance this view in the form of a criticism of Xenophon - who seems, if anything, to support it - Kierkegaard all but expressly dissociates Socrates from the idea of endoxabased inquiry. At one point, for instance, he pits Socrates' manner of conversing against the way of 'the crowd', whose discussions begin and end 'in a stagnating village pond', where the latter evidently stands for a common pool of belief and opinion (CI: 17). Kierkegaard adds that 'for Socrates, nothing was static in this sense', juxtaposing the image of the biblical pool which 'gave healing only when it was agitated' (CI: 17n).

The positive significance of the notion of a Socratic 'situation' becomes clearer in the light of a second feature. The Concept of Irony also portrays Socrates as distinctively inquisitive, as singled out by a certain 'art of questioning'. The emphasis here is indeed on the singular nature of this art, which Kierkegaard articulates through a contrast between asking [sporge] and interrogating [udsporge] (CI: 35). Socratic questioning, he claims, involves in a special way the interrogation or 'sounding out' of particular things, rather than the simple asking and answering of questions. More specifically, Kierkegaard thinks it is part and parcel of Socratic questioning to seek to render questionable particular thinkers' everyday grasp of familiar things. ${ }^{26}$ Accordingly, interlocutors figure in Socratic questioning primarily as targets of interrogation rather than as authoritative sources of information, or even as co-inquirers. It is precisely his interlocutors' everyday grasp of familiar things that Socrates seeks to put into question. ${ }^{27}$

Kierkegaard's idea, then, is that Socratic thinking is specifically situated with regard to particular thinkers and the judgements they make about familiar things. He further develops the contrast between asking and interrogating in a striking way, by appeal to the idea of a 'relation of necessity' between the Socratic questioner and the subjects of his elenchoi. ${ }^{28}$ What this means, I take it, is that it is part of the art of Socratic questioning to 'sound out' only that which is inherently questionable. ${ }^{29}$ Unlike the case of simple asking, in which the aim is presumably to find a good answer to the question(s) asked, the aim of Socratic questioning is to demonstrate that something is inherently questionable, subject to real aporiai. Thus, if what it is to 'ask' in a properly Socratic way is 
to make manifest that which is inherently questionable as such, and if what counts as an 'answer' in this context is just this outcome, Kierkegaard may conclude, with some justice, that here, as he puts it with a flourish, 'asking becomes identical with answering' (CI: 35).

As Kierkegaard conceives it, the Socratic art of questioning is to demonstrate that a given thinker's grasp of some basic concept is questionable, and to do so in such a way as to allow the search for an objective definition to emerge as a genuine requirement. ${ }^{30}$ However, such questioning is clearly not supposed to be sufficient to establish the correct grasp of the relevant concepts, that is, to establish an objective definition. On the contrary, Kierkegaard insists that positive essential knowledge is beyond the scope of Socratic questioning as such. In his preferred metaphor, it is characteristic of this questioning to deploy the ideas of essential knowledge and objective definition, formally and negatively, as a 'boundary' against which individuals' actual modes of thinking and judging are measured and ironically set in relief. ${ }^{31}$ This is why Kierkegaard presents it as a salutary moment in Plato's Apology when Socrates points to the joy of meeting after death the great men who have gone before and says that above all he should like to spend his time examining and searching people's minds. Kierkegaard comments:

Here we stand at a crucial point. It is undeniable that here Socrates almost lapses into the ridiculous in this zeal for spying on people that does not even allow him peace after death. And who, indeed, can keep from smiling when he imagines the somber shades of the underworld and Socrates right there in the middle, indefatigably interrogating them and showing them that they know nothing. (CI: 40)

The comical image is evidently of crucial significance for Kierkegaard because it intimates just how integral to Socrates' basic aims and interests is the interrogation of particular thinkers. And one notable corollary of Kierkegaard's account in this respect is that it stands opposed to any view in which the most basic points of departure in Socratic inquiry are located in 'What is F?' questions. It follows from Kierkegaard's appeal to the situated and inquisitive character of Socratic thinking that truly Socratic questions of this form properly emerge only against the well-defined background provided by the concrete process of interrogating particular thinkers about the things that are most familiar to them. And these background conditions are supposed to assume such decisive importance to Socrates not least because they make it possible for Socrates to demonstrate, case by case, that an objective definition is properly required in response to a question of the form 'What is F?'

Why does Kierkegaard think Socrates devoted himself to the elenchos, so conceived? As we have noted, one answer has it that he ascribes to Socrates a prior commitment to certain metaphysical doctrines that directly imply that the search for definitions itself is doomed to failure. But I want to suggest a different answer. For it is a 


\section{Daniel Watts}

third feature of Socratic thinking, on Kierkegaard's account, that such thinking is distinctively reflexive. As we have seen, Kierkegaard expressly characterises Socratic thinking in terms of 'reflection upon reflection' and suggests a parallel with post-Kantian idealism in this regard. What he has in mind, I take it, is the idea of reflexive critique, the idea, in Kant's terms, of a critique of reason by reason itself. Kierkegaard's appeal to this idea, however, is modulated by his understanding of the situated and inquisitive character of Socratic thinking. Socrates' philosophical practice is not the pure reflexivity of the relationship of pure thought to itself in Hegel's Logic, for example, but rather the situated and inquisitive reflexivity of a thinker whose interest primarily rests on the question of how he himself stands in relation to the demands of knowledge and wisdom. ${ }^{32}$

Plausibly, then, Kierkegaard regards Socrates' peculiar devotion to the elenchos as a consequence of his primary interest in self-knowledge, conceived as the ability to distinguish between what one does and does not know or understand. This is why, as Kierkegaard puts it, 'Socrates proves to be one who is ready to leap into something ... but leaps aside and back into himself (CI: 166). And Socrates' professions of ignorance are to be understood accordingly as expressions of his relentlessly inquisitive attitude towards himself. No doubt it is an important further question how the interrogative questioning of others is supposed to accord with the reflexive character of Socratic thinking. In his dissertation, at least, Kierkegaard seems content in this regard to appeal to The Apology and to Socrates' 'mission' to elicit the confession of ignorance from his interlocutors in the face of the demand for objective definitions. ${ }^{33}$

To sum up, The Concept of Irony offers an account of Socratic thinking as situated in a certain way, in virtue of its distinctively inquisitive and reflexive character. And we may summarise as follows how these descriptions contribute to a defence of Socrates against Hegel's criticism by reference to two general consequences of Kierkegaard's account:

(C1) There are conditions in which abstract ideas must be considered in relation to concrete persons.

(C2) There are conditions in which what a person thinks cannot be fully specified without reference to how a person thinks.

Firstly, Kierkegaard's account implies that Socratic thinking exemplifies the conditions mentioned in C1. It is constitutive of such thinking, on this account, to consider abstract contents of thought - arguments, propositions, reasons, claims, hypotheses, proposed definitions and the like - only in relation to the performances of particular thinkers considered in concreto. The unsystematic nature of Socrates' inquiries is, therefore, in no way adventitious, on this view, but must be regarded as essentially grounded in their basic aims and interests. And in response to the worry that there is something ad hoc or arbitrary about Socrates' procedure, Kierkegaard can appeal both to the Socratic art of questioning only that which is objectively questionable and to the place of such questioning within the overall context of Socrates' search for self-knowledge. 
Secondly, Kierkegaard's account implies that Socratic thinking exemplifies the conditions mentioned in C2. It follows from this account that it is not possible to specify Socrates' thoughts merely by reference to their contents, in terms of doctrines, arguments, conceptions of the Good and the like. This is not because Kierkegaard thinks that to try to do so would be incompatible with Socrates' metaphysical commitments, but because he thinks it would fail to take into account the specific character of how Socrates thinks, that is, the essentially situated character of his way of thinking. (I take it that this is not to deny that Socrates' thought can be partly specified by reference to, for instance, the doctrine that it is better to be harmed than to harm. The point is that any specification merely of this sort, however extensive, must remain radically incomplete.) It is at just this adverbial level - the level of what he calls 'the direction of the trend of Socrates' life' that Kierkegaard thinks Hegel's account most basically goes awry. Kierkegaard's concern is, therefore, not merely that Hegel misses the way in which Socrates' failure to produce a system is essentially grounded in his basic aims and interests, but also that Hegel fails to do justice to his own insight that it belongs to Socrates to exemplify a certain way of thinking rather than to bequeath a body of philosophical doctrine.

These points do not, of course, amount to a general defence of the aims of Socratic thinking, as Kierkegaard conceives these aims. He will only really develop such a defence in later works, by appeal to the special requirements on an appropriate response to questions regarding how to live. But insofar as Hegel's criticisms are supposed to be internal to Socrates' aims, we may conclude that The Concept of Irony does offer a cogent rejoinder in this regard. On our interpretation, this rejoinder does not rely on the idea that Socrates thinks it is somehow futile to search for knowledge beyond the recognition of one's ignorance. Rather, it relies on the idea that the contingent performances of particular thinkers enter into Socrates' most basic aims and interests. But I hope it is clear that this rejoinder is far from anodyne. For it implies that Hegel is too quick to present later developments in philosophical dialectic - including, ultimately, his own work - as more fully realising the aims implicit in Socrates' philosophical practice. ${ }^{34}$

\section{Daniel Watts}

Department of Philosophy

University of Essex

dpwatts@essex.ac.uk

\section{Notes}

Abbreviation: CI: Kierkegaard (1989)

${ }^{1}$ Kierkegaard (1909-48):VI: A145, English translation by George Pattison (2007): 28-29.

2 See, for example, Kierkegaard (1992): 34, 70 and 333.

${ }^{3}$ See, for example, Daise (1999), Sinett (2000), Pattison (2002a), Swenson (1983) and Meunch (2005). 


\section{Daniel Watts}

${ }^{4}$ For a discussion of the various stages in the development of Kierkegaard's view of Socrates, see Rubenstein (2001).

${ }^{5}$ Kierkegaard underlines the paradoxical nature of his project in the introduction to Part One of The Concept of Irony by comparing the attempt to 'picture a nisse with the cap that makes him invisible' (Kierkegaard 1989: 12).

${ }^{6}$ See, for example, CI: 218 and 261.

${ }^{7}$ Later in the dissertation, the charge that Hegel's view is fundamentally askew is repeated when Kierkegaard accuses Hegel of interpreting Socratic irony in a way that 'confuses everything' (CI: 267).

${ }^{8}$ See Williams (2002): 72ff.

9 The character and extent of Kierkegaard's irony in the dissertation is, of course, an interpretative morass in itself. For a discussion see, for example, Kofman (1998) and Pattison (2002b). But note that one of the ways in which Kierkegaard characterises irony within the text is as an 'equivocation' between earnestness and jest (see CI: 57); and Kierkegaard's own depiction of Socrates as a radical 'ironist' certainly displays this sort of equivocation. At any rate, my aim in this essay is to elucidate what Kierkegaard thinks in earnest in his early critical response to Hegel's Socrates.

${ }^{10}$ See, for example, Kierkegaard's reference to the one who 'cannot bear the absolute except in the form of nothing' apropos Socrates' attitude towards his death (CI: 77).

${ }^{11}$ Kierkegaard expressly dissociates Socrates from scepticism when he remarks that, unlike Socratic irony, '[e]ven skepticism always posits something' (CI: 56).

${ }^{12}$ As Kierkegaard puts it, "when Socrates declared that he was ignorant, he nevertheless did know something, for he knew about his ignorance; on the other hand, this knowledge was not a knowledge of something, that is, did not have any positive content' (CI: 269).

${ }^{13}$ See, for example, Most (2007) and Velkley (2006).

${ }^{14}$ Hegel makes this point clear in \$121 of the The Encyclopaedia Logic: 'As is well known, Socrates fought the Sophists on all fronts, but he did not do so just by setting authority and tradition against their abstract argumentation, but rather by ... vindicating against them the validity of what is just and good, the validity of the universal generally' (Hegel 1991: 191).

${ }^{15}$ In Hegel's words, '[Socrates] led consciousness back into itself in order to bring it to the universal, to the good' (Hegel 2006: 137, my emphasis).

${ }^{16}$ See CI: 17, 33, 46 and 191.

${ }^{17}$ In his classic study Plato's Earlier Dialectic, Robinson thus presents Socrates' purported interest in purely abstract questions as fundamentally disingenuous: 'The Socratic elenchus is a very personal affair, in spite of Socrates' ironic declarations that it is an impersonal search for truth' (Robinson 1962: 15). This claim might seem amenable to Kierkegaard, but it is clearly not his view. For Kierkegaard, on the contrary, Socrates' impersonal orientation towards truth is a crucial distinguishing feature of his mode of thought. What Kierkegaard does think is mere posture is any appearance within Plato's early dialogues that Socrates has a positive grasp of the concept under discussion. On Kierkegaard's account, this must be regarded as deception intended to help problematise or 'volatise' the concepts in question; but this is part and parcel of Socrates' sincere effort to reorient his interlocutors towards the search for objective definitions.

${ }^{18}$ That Kierkegaard does indeed mean to refer here to particular thinkers considered as epistemic agents - and not to the rational soul as such, for example - is evident from his following discussion of the Apology and of Socrates' 'divine mission' to dispel illusions of wisdom among his contemporaries.

${ }^{19}$ Thus, Kierkegaard writes freely of 'the Socratic sensibility' (CI: 17), 'the genuine Socratic method' (CI: 17), 'the true centre for Socrates' (CI: 16), 'the unalloyed Socratic' (CI: 40), '[what] belongs primarily to Socrates' (CI: 122), and so forth.

${ }^{20}$ See, for example, Kierkegaard (1992): 80-93. 
${ }^{21}$ One might develop this line of criticism, for example, by observing, with many more recent commentators, that it is difficult to see how the Socratic method of elenchos can hope to establish anything more than that certain sets of beliefs are internally inconsistent; see, for example, Vlastos (1983).

${ }^{22}$ Kangas is clear on this point: 'Socrates [in Hegel's view] actually knew nothing only in Hegel's terms of a systematic construction of philosophy. Yet, according to Hegel, Socrates' whole position aims, implicitly, at such a construction. Hence, the contradiction in the Socratic point of view: it proclaims a knowledge that it refuses to develop; it remains fixated upon an abstract right of questioning' (Kangas 2007: 18).

${ }^{23} \mathrm{I}$ argue that this attack has real force against Hegel in Watts (2007).

${ }^{24}$ See, for example CI: 32, 184 and 235. It is surely undeniable that, at the time of writing his dissertation, Kierkegaard partly shared Hegel's critical evaluation of Socrates, such that later on he could intelligibly regard his earlier self as a 'Hegelian fool' in this regard (see CI: 453). Plausibly, however, what the early Kierkegaard shared in a straightforward way with Hegel in this respect, and what he later repudiated, was the negative evaluation of the atomistic individualism both thinkers discerned in Socrates' ethical-political orientation.

${ }^{25}$ As Kierkegaard has it, 'instead of the good, we have the useful, instead of the beautiful the utilitarian, instead of the true the established, instead of the sympathetic the lucrative, instead of harmonious unity the pedestrian' (CI: 25).

${ }^{26}$ Accordingly, Kierkegaard frequently emphasises Socrates' capacity to dwell on such lowly matters as tanners, shepherds and pack asses (see CI: 17n).

${ }^{27}$ We may note here that one advantage of Kierkegaard's view is that it makes decent sense of the fact that, as Hugh Benson puts it, Socrates operates with strikingly weak constraints on 'premise acceptability', i.e., that he is prepared to accept any premise for the purposes of elenctic argumentation, if only the premise is believed by someone (see Benson 2002: 105). From Kierkegaard's point of view, this is just what we should expect since Socrates' aim is to use, inter alia, the claims he elicits from $\mathrm{N}$ regarding $F$ (not in order to refute some particular proposition regarding $F$ but) to show that $\mathrm{N}$ is properly subject to the demand for an objective definition of $F$. For these purposes, anything $\mathrm{N}$ admits is grist to the Socratic mill.

${ }^{28}$ In Kierkegaard's words, 'the reason for the individual's asking thus and so is found not in his arbitrariness but in the subject, in the relation of necessity that joins them together' (CI: 35).

${ }^{29}$ This interpretation is supported by the analogy with water divining which Kierkegaard suggests in a footnote: 'Just as a divining rod ... mysteriously communicates with the water hidden in the earth and wishes only where there is water' (CI: $35 n$ ).

${ }^{30}$ Thus, Kierkegaard summarises 'the overall movement' of Book I of Plato's Republic, which he regards as continuous with the early dialogues, in terms of 'a question dialectically evolving from the speakers' fatuities' which 'achieves the possibility of asking with speculative energy: What is justice?' (CI: 118). It must be said, however, that Kierkegaard offers us little by way of a detailed account of how the process he describes here is supposed to work.

${ }^{31}$ For the boundary metaphor, see CI: 169.

32 '[A] person relates himself to himself and the idea' as Kierkegaard characterises the Socratic standpoint in an entry in his 1850 journals (see Kierkegaard 1967: 28). On Kierkegaard's later objections to Hegel's conception of pure thought, see Watts (2007).

33 Elsewhere, Kierkegaard makes it clear he thinks the interplay between self and other in Socrates' search for self-knowledge has a more general significance; something which is already indicated by one of his favourite mottos, 'to strand alone - by another's help' (see, for example, Kierkegaard 1967: 280). But this is a topic for another occasion.

${ }^{34}$ In preparing this paper, I have benefited greatly from many conversations with David McNeill and Vasilis Politis, so I warmly thank them both. Thanks also to all who responded to the paper at the meeting of the Hegel Society of Great Britain in Oxford, September 2009. 


\section{Daniel Watts}

\section{Bibliography}

Benson, H. (2002), 'Problems with Socratic Method' in G. A. Scott (ed.), Does Socrates have a Method? Rethinking the Elenchus in Plato's Dialogues and Beyond. Pennsylvania, PA: Pennsylvania State Press.

Capel, L. M. (1971), 'Introduction' in S. Kierkegaard, The Concept of Irony, with Constant Reference to Socrates, trans. L. M. Capel. Bloomington: Indiana University Press.

Daise, B. (1999), Kierkegaard's Socratic Art. Macon, GA: Mercer University Press.

Hegel, G. W. F. (1985), Hegel's Introduction to the Lectures on the History of Philosophy, trans. T. M. Knox and A. V. Miller. Oxford: Clarendon.

Hegel, G. W. F. (1991), The Encyclopaedia Logic, trans. T. F. Geraets, W. A. Suchting and H. S. Harris. Indianapolis, IN: Hackett.

Hegel, G. W. F. (1995), Lectures on the History of Philosophy I: Greek Philosophy to Plato, trans. E. S. Haldane and F. H. Simson. London: University of Nebraska Press.

Hegel, G. W. F. (2006), Lectures on the History of Philosophy 1825-6 Volume II: Greek Philosophy, trans. R. F. Brown. Oxford: Oxford University Press.

Kierkegaard, S. (1909-48), Papirer, ed. J Heiberg, V. Kuhr and E. Torsting. Copenhagen: Gyldendal. (Please provide number of volumes?)

Kierkegaard, S. (1967), Soren Kierkegaard's Journals and Papers, trans. H. V. Hong and E. H. Hong, I: A-E. Princeton: Princeton University Press.

Kierkegaard, S. (1989), The Concept of Irony with Continual Reference to Socrates; Schelling Lecture Notes, trans. H. V. Hong and E. H. Hong. Princeton: Princeton University Press.

Kierkegaard, S. (1992), Concluding Unscientific Postscript to the Philosophical Fragments, trans. H. V. Hong and E. H. Hong. Princeton: Princeton University Press.

Kofman, S. (1998), Socrates: Fictions of a Philosopher. London: Athlone.

Most, G. W. (2007), 'Socrates in Hegel' in M. B. Trapp (ed.), Socrates in the Nineteenth and Twentieth Centuries. Hampshire: Ashgate.

Muench, P. (2005), 'Kierkegaard's Socratic Point of View' in S. Ahbel-Rappe and R. Kamtekar (eds.), A Companion to Socrates. Oxford: Blackwell.

Pattison, G. (2002a), Kierkegaard's Upbuilding Discourses: Philosophy, Literature and Theology. London: Routledge.

Pattison, G. (2002b), 'Beyond the Grasp of Irony' in R. Perkins (ed.), International Kierkegaard Commentary: The Concept of Irony. Macon, GA: Mercer University Press.

Pattison, G. (2007), 'A Simple Wise Man of Ancient Times: Kierkegaard on Socrates' in M. B. Trapp (ed.), Socrates in the Nineteenth and Twentieth Centuries. Hampshire: Ashgate.

Robinson, R. (1962), Plato's Earlier Dialectic, 2nd ed. Oxford: Clarendon.

Rubenstein, M-J. (2001), 'Kierkegaard's Socrates: A Venture in Evolutionary Theory', Modern Theology 17: 442-73. 
Sinett, M. W. (2000), Socratic Dialectic in the Authorship of Soren Kierkegaard. Fife: Theology in Scotland.

Stewart, J. (2007), 'Hegel: Kierkegaard's Reading and Use of Hegel's Primary Texts' in J. Stewart (ed.), Kierkegaard and his German Contemporaries, Tome I: Philosophy. Hampshire: Ashgate.

Swenson, D. F. (1983), 'Søren Kierkegaard - a Danish Socrates' in D. F. Swenson, Something about Kierkegaard. Macon, GA: Mercer University Press.

Velkley, R. L. (2006) 'On Possessed Individualism: Hegel, Socrates' Daimon, and the Modern State', The Review of Metaphysics, 59:3: 577-99.

Vlastos, G. (1983) 'The Socratic Elenchus', Oxford Studies in Ancient Philosophy I: 27-58.

Watts, D. (2007) 'The Paradox of Beginning: Hegel, Kierkegaard and Philosophical Inquiry', Inquiry 50:1: 5-33.

Williams, R. (2002), 'Hegel on Socrates and Irony' in D. Duquette (ed.), Hegel's History of Philosophy: New Interpretations. Albany: SUNY Press. 